\section{Chlorophyll, Carotenoid, and Visual Color Rating of Japanese-cedar Grown in the Southeastern United States}

\author{
Ryan N. Contreras ${ }^{1,4}$ \\ Department of Horticulture, Oregon State University, 4017 Agricultural and \\ Life Sciences Building, Corvallis, OR 97331
}

John M. Ruter ${ }^{2}$

Allan Armitage Professor of Horticulture, Department of Horticulture, University of Georgia, 221 Hoke Smith, Athens, GA 30602

James S. Owen, Jr. ${ }^{1}$

Department of Horticulture, Virginia Polytechnic Institute and State University, Hampton Roads Agricultural Research and Extension Center, 1444 Diamond Springs Road, Virginia Beach, VA 23455

\section{Andy Hoegh ${ }^{3}$}

Laboratory for Interdisciplinary Statistical Analysis, Department of Statistics, Virginia Polytechnic Institute and State University, 406-A Hutcheson Hall, Blacksburg, VA 24061

Additional index words. Cryptomeria japonica, photoinhibition, pigments, winter-browning

\begin{abstract}
Japanese-cedar has been underused in landscapes of the United States until recent years. There are now over 100 cultivars, many of which are grown in the southeast of the United States. Performance of cultivars has been described from U.S. Department of Agriculture (USDA) Zone 6b to USDA Zone 7b; however, there are no reports on how cultivars perform in USDA Zone 8. The current study was conducted to measure chlorophyll $a$, chlorophyll $b$, total chlorophyll, and carotenoid content and assign visual color ratings to determine if there was a relationship between pigment values and perceived greenness, which generally is regarded as a desirable and potentially heritable trait. Total chlorophyll $(P=0.0051)$, carotenoids $(P=0.0266)$, and the ratio of total chlorophyll to carotenoids $(P=\mathbf{0 . 0 1 8 8})$ exhibited a positive relationship with greenness after accounting for season and tree effects. In contrast, the ratio of chlorophyll $a$ to chlorophyll $b$ did not have an effect on greenness. There was a linear relationship between total chlorophyll and carotenoid regardless of season (summer $R^{2}=0.94$; winter $R^{2}=0.88$ ) when pooled across 2 years. The observed correlation between chlorophyll and carotenoid content suggests they could be used interchangeably as predictors of greenness. There were large differences in rainfall between the 2 years that may have resulted in additional variation. Furthermore, the climate in which the evaluation was conducted differs greatly from the native distribution of japanese-cedar occurring in China and Japan.
\end{abstract}

Japanese-cedar [Cryptomeria japonica (L.f.) D. Don] is a variable conifer that grows up to $60 \mathrm{~m}$ tall in its native range. Wild-type specimens are conical when young and become cylindrical with age (Eckenwalder, 2009). Japanese-cedar traditionally has been used as screening or specimen plantings; however, there are a large number of cultivars displaying varying forms and growth rates (Rouse et al., 2000; Tripp, 1993) that may be used in

\footnotetext{
Received for publication 16 Sept. 2013. Accepted for publication 28 Oct. 2013.

We thank Nancy Hand, Bruce Tucker, and Zhibing $\mathrm{Xu}$ for their technical assistance.

${ }^{1}$ Assistant Professor.

${ }^{2}$ Professor.

${ }^{3} \mathrm{PhD}$ Candidate.

${ }^{4}$ To whom reprint requests should be addressed; e-mail contrery@hort.oregonstate.edu.
}

ephemeraeformis Haworth) (Lemke et al., 2005), fungal cankers caused by Seiridium Nees ex Link spp. and Botryosphaeria dothidea (Moug.) Ces. et De Not., and cercospora needle blight (Cercosporidium sequoiae Ellis and Everh.) (Martinez et al., 2009). Japanesecedars exhibit less susceptibility to bagworm infestations, and cultivars are available that have reduced interior branch death (Tripp and Raulston, 1992); however, the species is not problem-free. Redfire (Phyllosticta aurea C.Z. Wang) is a fungal pathogen that can attack stressed japanese-cedars and cause stem death, particularly on older foliage (Cox and Ruter, 2013; Tripp, 2005). Also, as Dirr (2009) notes, there is not a fast-growing, treelike cultivar that remains green during winter. Winter browning in japanese-cedar is often unsightly and undesirable to consumers, which may have contributed to why it has remained underused in landscapes.

Winter browning in japanese-cedar occurs through the conversion of chloroplasts to chromoplasts during winter (Ida, 1981). This transition takes place only in sun-exposed leaves during periods of low temperature, indicating that photoinhibition likely plays a role (Han and Mukai, 1999; Ida, 1981). Plants have several mechanisms to cope with excess light during periods of low temperature when Calvin cycle activity is limiting, including reduction of chlorophyll, $\mathrm{pH}$-dependent xanthophyll cycle, increased levels of carotenoids, and production of antioxidants or reactive oxygen species (ROS) scavenging enzymes. During winter, japanese-cedar has been shown to demonstrate two principle mechanisms to deal with excess light energy. The amount of chlorophyll decreases during winter (Han and Mukai, 1999; Ida, 1981) in both sunand shade-exposed leaves (Han et al., 2004). This occurs in both wild-type and nonbrowning mutants (Han et al., 2003), thus reducing the amount of energy absorbed. The other mechanism is the conversion of chloroplasts in sun-exposed leaves to rhodoxanthin-containing chromoplasts during winter to dissipate excess light energy as heat (Ida, 1981).

In a study on 15-year-old japanese-cedar trees in Shizuoka Prefecture, Japan, Han et al. (2004) reported accumulation of rhodoxanthin in sun-exposed leaves beginning in January, reaching maximum levels in February, decreasing significantly in March, and falling to zero by April. However, timing of discoloring in winter and restoration in spring is highly variable and location-specific (personal observation). Han et al. (2003) demonstrated that wild-type leaves that accumulated rhodoxanthin maintained higher levels of photosynthesis with lower levels of zeaxanthin- and antheraxanthin-dependent thermal dissipation than mutants that remained green all winter. The proposed role of rhodoxanthin is to intercept a portion of incident light to help maintain an appropriate balance among light absorption, thermal dissipation, and photosynthesis (Han et al., 2003). Japanese-cedar also accumulated substantial levels of xanthophyll cycle pigments and lutein during 
winter (Han et al., 2003; Han and Mukai, 1999).

The overarching objective of the current study was to identify an early predictor of winter foliage color (resistance to leaf browning) in japanese-cedar as a screening tool for identifying superior selections. Specifically, we assessed if quantitating pigments such as total chlorophyll $\left(C_{a+b}\right)$, ratio of chlorophyll $a\left(C_{a}\right)$ :chlorophyll $b\left(C_{b}\right)$, total carotenoids $\left(C_{x+c}\right)$, and ratio of $\left(C_{a+b}\right):\left(C_{x+c}\right)$ exhibited a strong relationship with greenness as measured by visual color rating at the University of Georgia Tifton Campus (USDA Zone 8b; USDA-ARS, 2012).

\section{Materials and Methods}

Plant material and growing conditions. Single plants of the following 12 taxa of japanese-cedar were randomly planted in 1997: 'Araucariodes', 'Ben Franklin', 'Black Dragon', 'Cristata', 'Gyokruga', 'Rasen', 'Sekkan', 'Tansu', 'Tarheel Blue', var. sinensis, 'Yaku', and 'Yoshino'. These taxa were not meant to provide an evaluation of each per se as a result of single replicates; rather, they were used to provide a general sampling of the genotypic and phenotypic diversity observed in landscape forms of japanesecedar. Plants were maintained in field plots at the University of Georgia Tifton Campus (lat. $31^{\circ} 49^{\prime} \mathrm{N}$, long. $83^{\circ} 53^{\prime} \mathrm{W}$; USDA Zone $8 b$ ). Field soil was a Tifton loamy sand (fineloamy, siliceous, thermic Plinthic Paleudult), $\mathrm{pH}$ 5.2. Plots were fertilized in March every year after planting at a rate of $56 \mathrm{~kg} \cdot \mathrm{ha}^{-1}$ nitrogen $(\mathrm{N})$ using Super Rainbow 16N-1.8P6.6K plus minor elements (Agrium U.S. Inc., Denver, CO). An additional $28.5 \mathrm{~kg} \cdot \mathrm{ha}^{-1} \mathrm{~N}$ was applied in late August each year after planting using the product mentioned previously. Southeast-facing branches were flagged during winter 2007-08 and material used for the duration of the study was collected from the same branches. Leaves were collected 8 Feb. 2008, 17 Aug. 2008, 9 Feb. 2009, and 5 May 2009 and frozen at $-80^{\circ} \mathrm{C}$ until analysis. Temperature and precipitation data at the Tifton Campus for the duration of the study are included in Table 1. Supplemental irrigation was used only at the time of new plant establishment within plots.

Chlorophyll and carotenoid extraction, analysis, and calculations. Three subsamples of leaf tissue were collected from the 12 individuals and $C_{a+b}$ and $C_{x+c}$ were extracted by grinding $85 \mathrm{mg}$ leaf tissue three times in $3.33 \mathrm{~mL} 80 \%$ aqueous acetone and the extract was transferred to a test tube and brought to a final volume of $10 \mathrm{~mL}$. After the third grind in acetone, the leaf material remaining was transferred to the test tube containing the extract and maintained in the dark at $4{ }^{\circ} \mathrm{C}$ for $1 \mathrm{~h}$ to ensure complete extraction. Two milliliters of the extract was centrifuged for $30 \mathrm{~s}$ at $6800 \mathrm{~g}_{\mathrm{n}}$. The supernatant was then transferred to a cuvette and absorbance was measured at $470 \mathrm{~nm}, 646 \mathrm{~nm}$, and $663 \mathrm{~nm}$ using a GENESYS ${ }^{\mathrm{TM}} 10$ Spectrophotometer (Thermo Electron Corp., Madison, WI). Absorbance for all samples at each wavelength was between 0.2 and 0.8 .

Determination of $C_{a}, C_{b}$, and $C_{x+c}$ was performed using calculations from Lichtenthaler and Wellburn (1983). $C_{a}$ content was calculated using the formula: $C_{a}\left(\mathrm{mg} \cdot \mathrm{L}^{-1}\right)=$ $\left(12.25 \times A_{663}\right)-\left(2.79 \times A_{646}\right) . C_{b}$ content was calculated using the formula: $C_{b}\left(\mathrm{mg} \cdot \mathrm{L}^{-1}\right)=$ $\left(22.5 \times A_{646}\right)-\left(5.1 \times A_{663}\right) . C_{a+b}$ content was determined by summing $C_{a}$ and $C_{b}$ values. Total carotenoid content was determined using the formula: $C_{x+c}\left(\mathrm{mg} \cdot \mathrm{L}^{-1}\right)=[1000 \times$ $\left.A_{470}-\left(1.82 \times C_{a}\right)-\left(85.02 \times C_{b}\right)\right] / 198$. Chlorophyll and carotenoid contents were expressed in $\mathrm{mg} \cdot \mathrm{g}^{-1}$ of dry weight after being corrected for moisture content (MC) as follows: three unanalyzed leaf subsamples were

Table 1. Temperature and precipitation data at the University of Georgia Tifton Campus ${ }^{\mathrm{z}}$ for the duration of a study to evaluate pigments and color of Cryptomeria japonica from Nov. 2007 through Aug. 2009.

\begin{tabular}{lcccc}
\hline Month & $\begin{array}{c}\text { Avg daily maximum } \\
\text { temp }\left({ }^{\circ} \mathrm{C}\right)\end{array}$ & $\begin{array}{c}\text { Avg daily minimum } \\
\text { temp }\left({ }^{\circ} \mathrm{C}\right)\end{array}$ & $\begin{array}{c}\text { Avg daily } \\
\text { temp }\left({ }^{\circ} \mathrm{C}\right)\end{array}$ & Rainfall $(\mathrm{cm})$ \\
\hline Nov. 2007 & 20.8 & 7.4 & 14.1 & 2.3 \\
Dec. 2007 & 19.4 & 8.0 & 13.7 & 14.4 \\
Jan. 2008 & 14.0 & 3.9 & 8.9 & 8.7 \\
Feb. 2008 & 18.9 & 5.6 & 12.2 & 19.9 \\
Mar. 2008 & 20.9 & 8.5 & 14.7 & 8.1 \\
Apr. 2008 & 24.1 & 13.0 & 18.6 & 7.7 \\
May 2008 & 28.8 & 17.1 & 22.9 & 4.7 \\
June 2008 & 32.5 & 21.0 & 26.7 & 5.8 \\
July 2008 & 32.3 & 21.8 & 27.0 & 8.4 \\
Aug. 2008 & 30.7 & 21.9 & 26.3 & 31.3 \\
Sept. 2008 & 29.8 & 19.3 & 24.5 & 0.4 \\
Oct. 2008 & 23.7 & 12.5 & 18.1 & 16.3 \\
Nov. 2008 & 18.5 & 6.7 & 12.6 & 9.9 \\
Dec. 2008 & 18.8 & 7.5 & 13.1 & 7.9 \\
Jan. 2009 & 15.7 & 4.7 & 10.2 & 4.2 \\
Feb. 2009 & 17.1 & 4.3 & 10.7 & 5.5 \\
Mar. 2009 & 20.9 & 9.6 & 15.3 & 20.9 \\
Apr. 2009 & 24.0 & 12.6 & 18.3 & 21.0 \\
May 2009 & 27.6 & 18.6 & 23.1 & 16.6 \\
June 2009 & 32.8 & 22.3 & 27.6 & 5.0 \\
July 2009 & 31.7 & 21.6 & 26.6 & 17.6 \\
Aug. 2009 & 31.5 & 22.0 & 26.7 & 17.8 \\
\hline
\end{tabular}

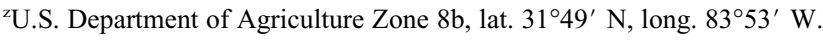

collected to determine mean $\mathrm{MC}$ for each individual (replicate) for each harvest date using the formula $\{\mathrm{MC}=[$ (initial weight dry weight $) /$ initial weight $] \times 100\}$

Color rating. Plants were observed within 1 week of the four leaf collection dates. Five evaluators assigned color ratings from 1 (very brown/yellow; off color) to 5 (very green). Ratings of 3.5 to 4 would be considered acceptable for landscape use. All plants were addressed from the southeast side, directly in front of flagged branches. Mean rating for each individual was calculated and used for statistical analysis.

Design and statistical analysis. The experimental design used repeated measurements across winter and summer on each individual with subsamples taken on the individual branches. Relevant covariate information, chlorophyll and carotenoid measurements, was obtained for each subsample, whereas the target response, color rating, was characterized at the individual level.

To assess the relationship between chlorophyll and carotenoid measurements with the observed color rating of the trees, data were analyzed using a mixed model framework (PROC MIXED, SAS Version 9.3; SAS Institute Inc., Cary, NC). Random intercept models (linear models with random components with each variant of tree having a different intercept, but the slopes are assumed the same) were constructed to assess the relationship between the chlorophyll and carotenoid measurements with the observed greenness of the trees. These models were of the form:

$$
\begin{aligned}
& \text { Green }_{i j k}=\mu+\text { tree }_{i}+\text { season }_{j} \\
& +\beta^{*} \text { covariate }_{i j k}+E_{i j k}, \\
& \text { tree }_{i} \sim N\left(0, \sigma_{t}\right), E_{i j k} \sim N\left(0, \sigma_{E}\right) .
\end{aligned}
$$

To determine an overall best model, Akaike's Information Criterion (AIC) was used, in which a lower number represents a better fit. Also of interest in this research was to test for differences across the seasons in color ratings and chlorophyll and carotenoid easurements. For each measured pigment, a mixed-effects analysis of variance was constructed

Pigment $_{i j k}=\mu+$ tree $_{i}+$ season $_{j}+E_{i j k}$,

tree $_{i} \sim N\left(0, \sigma_{t}\right), E_{i j k} \sim N\left(0, \sigma_{E}\right)$

Hence, examining season term for each of these five models established whether there were seasonal differences in each pigment. The previous two statistical analyses aggregated the subsamples such that a single observation per tree per period was used.

To assess whether summer greenness measures are predictive of winter greenness, a simple regression model was used, for which summer and winter greenness ratings were aggregated for each individual. Given the experimental constraints in which only a single tree from each taxon could be planted, there is no replication of taxa. Hence, statistical methods cannot be used to determine 
whether certain cultivars or varieties exhibit higher greenness ratings. Rather, our objective here was to use these named taxa to determine if $C_{a}, C_{b}, \mathrm{C}_{a+b}$, or $C_{x+c}$ can be used in a model to predict winter greenness for $C$. japonica.

\section{Results}

$C_{a+b}(P=0.0051), C_{x+c}(P=0.0266)$, and the ratio of $C_{a+b}$ to $C_{x+c}(P=0.0188)$ exhibited a positive relationship with greenness after accounting for season and tree effects (Table 2). In contrast, the ratio of $C_{a}$ to $C_{b}$ was not related to greenness. Using $\mathrm{AIC}$, both $C_{x+c}(\mathrm{AIC}=91.7)$ and $C_{a+b}(\mathrm{AIC}=$ 91.9) have superior model fits than ratio of $C_{x+c}$ to $C_{a+b}(\mathrm{AIC}=93.2)$. Similarly, visual color rating correlated with $C_{a+b}(r=0.535)$, total $C_{x+c}(r=0.375)$, and their ratio $(r=$ 0.520 ) when pooled across years (Table 3 ). In addition, there was linear relationship between $C_{a+b}$ and $C_{x+c}$ regardless of season, summer $\left(R^{2}=0.94\right)$ and winter $\left(R^{2}=0.88\right)$, when pooled across 2 years (Fig. 1). The slope of the relationship $\left(\mathrm{y}=C_{x+c} ; \mathrm{x}=C_{a+b}\right)$ remained relatively consistent (4.47 and 5.05) across seasons; however, the intercept, a measure of $C_{x+c}$ levels, decreased for 0.52 to -1.35 from summer to winter, respectively (Fig. 1)

Each of the five attributes, observed greenness and measured chlorophyll and carotenoids, exhibited differences between summer and winter with higher values in the summer (Table 4). Using observed summer greenness pooled across years, winter greenness can be modeled $\left(P=0.017, R^{2}=\right.$ 0.45) (Fig. 2).

\section{Discussion}

Mean $C_{a+b}$ content was similar to previous values for japanese-cedar (Ida, 1981).
There were differences in mean $C_{a+b}$ between seasons with a higher content in summer than winter when taxa were pooled (Table 4). Previous studies also have observed reduction in $C_{a+b}$ content during winter in japanese-cedar (Han et al., 2003, 2004) and sitka spruce [Picea sitchensis (Bong.) Carr.] (Lewandowska and Jarvis, 1977). However, no increase in $C_{a+b}$ or alteration of $C_{a}: C_{b}$ ratio (discussed subsequently) was observed during spring recovery of Scots pine (Pinus sylvestris L.) from winter stress (Ottander and Öquist, 1991).

In Winter 2007-08, chlorophyll fluorescence was measured as an estimate of photosystem II (PSII) efficiency to assess damage. However, the values collected were extremely inconsistent (data not shown) and measurements were discontinued. Previous studies have successfully measured chlorophyll fluorescence (Han et al., 2003, 2004; Han and Mukai, 1999); however, the data we collected were not useful in evaluation of efficiency or damage to PSII. Therefore, we observed the relationship between $C_{a}: C_{b}$ in an attempt to estimate the status of the photosynthetic apparatus. The ratio of $C_{a}: C_{b}$ was lower in the winter than the summer (Table 4), which agrees with Han and Mukai (1999) who observed a slight decrease in the $C_{a}: C_{b}$ ratio of japanese-cedar during the period in which chlorophyll was being lost (early winter). This also agrees with the findings of Wolf (1956) who observed this phenomenon in 25 tree species, although that study was conducted solely on angiosperms. The reverse was observed in sitka spruce, which showed a slight increase in $C_{\mathrm{a}}: C_{b}$ ratio during winter (Lewandowska and Jarvis, 1977). A decreased ratio of $C_{\mathrm{a}}: C_{b}$ indicates that PSII reaction centers are affected more than light-harvesting complexes, because $C_{b}$

Table 2. Mean total chlorophyll $\left[C_{(a+b)}\right]$, ratio of chlorophyll $a\left(C_{a}\right)$ :chlorophyll $b\left(C_{b}\right)$, total carotenoid $\left[C_{(x+c)}\right]$, and visual color rating (Rating) of 12 replicates comprised of the same number of different taxa of Cryptomeria japonica evaluated at the University of Georgia Tifton Campus ${ }^{2}$ during winters of 2007-08 and 2008-09 and summers of 2008 and 2009.

\begin{tabular}{llcccc}
\hline Season & $C_{a+b^{\mathrm{y}}}$ & $C_{a}: C_{b}{ }^{\mathrm{x}}$ & $C_{x+c}{ }^{\mathrm{w}}$ & $C_{a+b}: C_{x+c}$ & Rating $^{\mathrm{v}}$ \\
\hline Winter 2007-08 & 2.82 & 2.57 & 0.85 & 3.28 & 2.98 \\
Summer 2008 & 3.98 & 2.78 & 0.83 & 4.83 & 3.23 \\
Winter 2008-09 & 2.30 & 2.59 & 0.7 & 3.24 & 2.56 \\
Summer 2009 & 4.8 & 2.81 & 0.91 & 5.28 & 3.60 \\
\hline
\end{tabular}

${ }^{2}$ U.S. Department of Agriculture Zone 8b, lat. $31^{\circ} 49^{\prime} \mathrm{N}$, long. $83^{\circ} 53^{\prime} \mathrm{W}$.

${ }^{\mathrm{y}}$ Mean $C_{a+b}$ in $\mathrm{mg} \cdot \mathrm{g}^{-1}$ dry weight.

${ }^{\mathrm{x}}$ Mean ratio of $C_{a}: C_{b}$.

${ }^{\text {w}}$ Mean $C_{x+c}$ in $\mathrm{mg} \cdot \mathrm{g}^{-1}$ dry weight.

${ }^{\mathrm{v}}$ Visual color rating based on color with $1=$ yellow or brown and $5=$ green.

Table 3. Correlation between total chlorophyll $\left(C_{a+b}\right)$, ratio of chlorophyll $a$ :chlorophyll $b\left(C_{a}: C_{b}\right)$, total carotenoids $\left(C_{x+c}\right)$, ratio of $C_{a+b}: C_{x+c}$, and visual color rating (Rating) of 12 replicates comprised of the same number of different taxa of Cryptomeria japonica evaluated at the University of Georgia Tifton Campus $^{2}$ during winters of 2007-08 and 2008-09 and summers of 2008 and 2009.

\begin{tabular}{llllll}
\hline & $C_{a+b}$ & $C_{a}: C_{b}$ & $C_{x+c}$ & $C_{a+b}: C_{x+c}$ & Rating \\
\hline$C_{a+b}$ & 1.00 & 0.048 & $0.805^{* * *}$ & $0.840^{* * *}$ & $0.535^{* * *}$ \\
$C_{a}: C_{b}$ & & 1.00 & -0.259 & $0.304^{*}$ & 0.165 \\
$C_{x+c}$ & & 1.00 & $0.382^{* *}$ & $0.375^{* *}$ \\
$C_{a+b}: C_{x+c}$ & & & 1.00 & $0.520^{* *}$ \\
Rating & & & & & 1.00 \\
\hline
\end{tabular}

${ }^{\mathrm{z}}$ U.S. Department of Agriculture Zone $8 \mathrm{~b}$, lat. $31^{\circ} 49^{\prime} \mathrm{N}$, long. $83^{\circ} 53^{\prime} \mathrm{W}$.

*,**,*** indicate significance at $P \leq 0.05, P \leq 0.01$, and $P<0.0001$, respectively.

is found only in the light-harvesting complexes and $C_{a}$ is part of the PSII reaction center (Hoober, 1998). Furthermore, characterization of the subunits of PSII reaction center has identified the D1 subunit's involvement in photoinhibition (He and Malkin, 1998) and Sandmann and Scheer (1998) reported that pheophytin $a$ (demetalated $C_{a}$ ) may be used as a marker for PSII.

Differences were observed between seasons for $C_{x+c}$ (Table 4). Robakowski (2005) observed a reduction in total carotenoid content in norway spruce [Picea abies (L.) Karst.] and mugo pine (Pinus mugo Turra) during winter but carotenoid content remained stable for silver fir (Abies alba Mill.). Differences were attributed to the latter species' ability to maintain high photosynthetic capacity during winter as its mechanism for preventing oxidative stress (Robakowski, 2005). We measured total carotenoid content in japanese-cedar leaves, whereas previous studies separated carotenoids (Han et al., 2003, 2004; Han and Mukai, 1999). However, the value for yellow carotenoids presented by Ida (1981) appears comparable to our values.

A positive, linear relationship was found between $C_{a+b}$ and $C_{x+c}$ in the current study in all seasons (Table 3 ). When data were pooled over 36 taxa belonging to Gymnospermae, Ida (1981) found a similar relationship. This relationship seems counterintuitive because chlorophyll decreases and carotenoids increase during winter (Han et al., 2003, 2004). Oserkowsky (1932) reported data that appeared to fit a positive linear relationship between yellow pigments (xanthophyll) and chlorophyll of hardy pear (Pyrus communis L.). That study cites other research (Sjöberg, 1931; von Euler and Hellström, 1929) that reported a simultaneous increase in green and yellow pigments in etiolated seedlings. The physiological basis for the concomitant increase in chlorophyll and carotenoids has been established as a means to prevent photooxidative damage resulting from ROS (Lambers et al., 1998). Excess energy is present, particularly during winter, because light capture and energy transfer occur more rapidly than the downstream biochemical reactions. However, carotenoids accumulate during winter and prevent damage by dissipating this excess energy as heat (Lambers et al., 1998).

There was a statistically significant relationship between both $C_{a+b}$ and $C_{x+c}$ content with visual rating. The hypothesis at the beginning of the experiment was that $C_{a+b}$ content may be used as a predictor of eventual field performance; the higher $C_{a+b}$ content, the more green the plants would remain in winter. We failed to reject this hypothesis. Previous studies have observed linear (Marquard and Tipton, 1987; Yadava, 1986) and quadratic (Netto et al., 2005) relationships between SPAD readings [SPAD-501 (Marquard and Tipton, 1987; Yadava, 1986); SPAD-502 (Netto et al., 2005)] and total chlorophyll content determined spectrophotometrically. In our study, $C_{x+c}$ also had a predictive relationship with observed greenness. This may be explained by the simultaneous increase in 


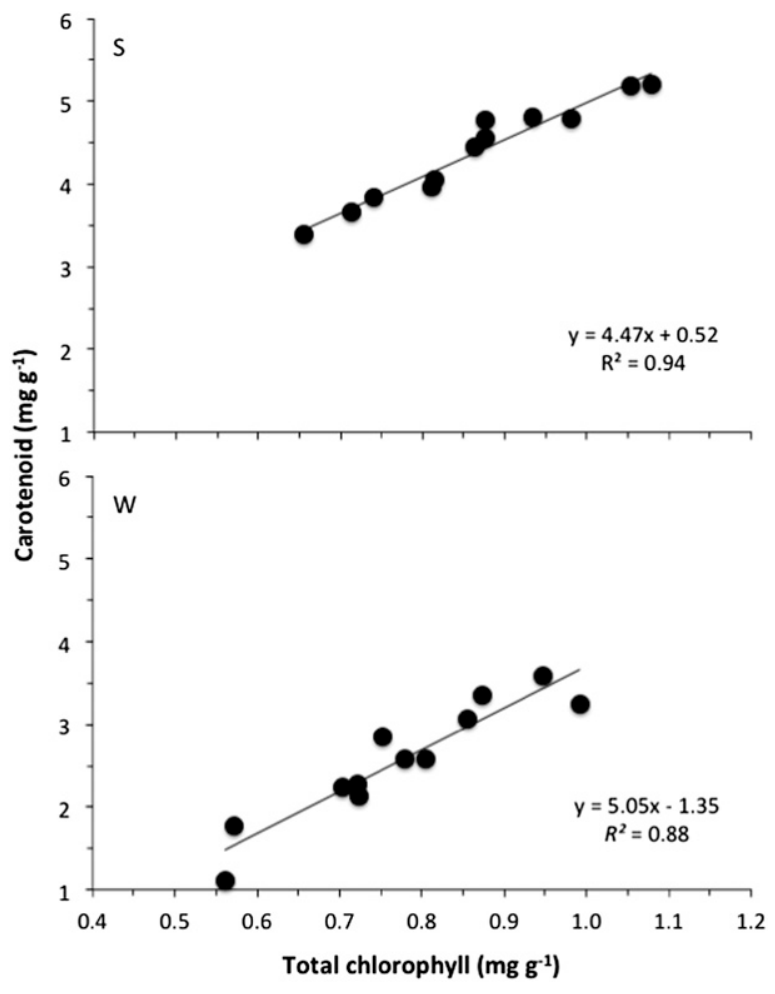

Fig. 1. Linear regression of total chlorophyll content over total carotenoid content in summer (S) or winter (W), pooled across 2 years, 12 replicates comprised of the same number of different taxa of Cryptomeria japonica evaluated at the University of Georgia Tifton Campus (U.S. Department of Agriculture Zone 8 b, lat. $31^{\circ} 49^{\prime} \mathrm{N}$, long. $83^{\circ} 53^{\prime} \mathrm{W}$ ). The values for $\mathrm{S}$ and $\mathrm{W}$ are means of the 2 years.

Table 4. A mixed effects analysis of variance ${ }^{\mathrm{z}}$ (ANOVA) table to evaluate seasonal differences, summer minus winter, of total chlorophyll $\left(C_{a+b}\right)$, ratio of chlorophyll $a$ :chlorophyll $b\left(C_{a}: C_{b}\right)$, total carotenoids $\left(C_{x+c}\right)$, ratio of $C_{a+b}: C_{x+c}$, and visual color rating (Rating) of 12 replicates comprised of the same number of different taxa of Cryptomeria japonica evaluated at the University of Georgia Tifton Campus ${ }^{y}$ pooled across years 2007 09 (winters) and 2008-09 (summers).

\begin{tabular}{|c|c|c|c|}
\hline Covariate & Estimate & $\mathrm{SE}$ & $P$ \\
\hline$\overline{C_{a+b}{ }^{\mathrm{x}}}$ & 1.8260 & 0.2078 & $<0.0001$ \\
\hline$C_{a}: C_{b}$ & 0.2144 & 0.04233 & $<0.0001$ \\
\hline$C_{x+c}{ }^{\mathrm{w}}$ & 0.09274 & 0.03953 & 0.0248 \\
\hline$C_{(a+b)}: C_{(x+c)}$ & 1.7999 & 0.1158 & $<0.0001$ \\
\hline Rating & 0.6167 & 0.1449 & $<0.0001$ \\
\hline
\end{tabular}

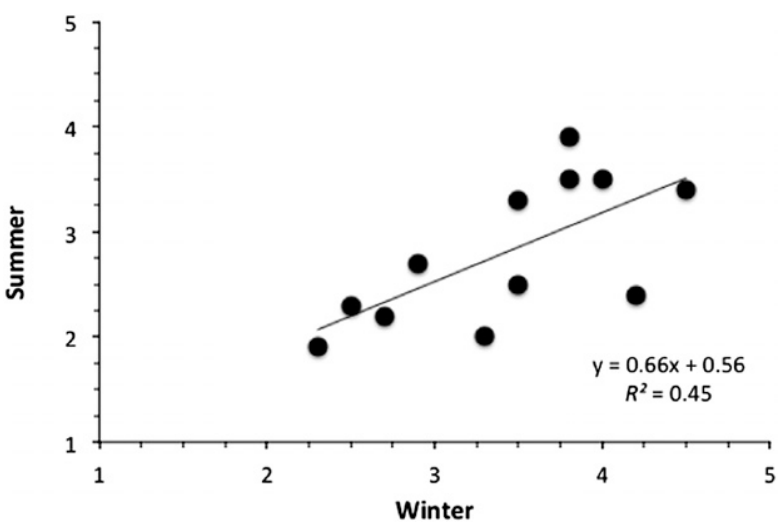

Fig. 2. Linear relationship of summer vs. winter greenness determined by visual color rating [1 (very brown/yellow; off color) to 5 (very green)] for Cryptomeria japonica evaluated at the University of Georgia Tifton Campus (U.S. Department of Agriculture Zone 8b, lat. $31^{\circ} 49^{\prime} \mathrm{N}$, long. $83^{\circ} 53^{\prime} \mathrm{W}$ ). Data points for 12 individuals are means over both years of the study. carotenoids and chlorophyll discussed previously, which is supported by the fact that we also observed a positive relationship between the ratio of $C_{a+b}$ to $C_{x+c}$ with greenness. This correlation may be used to predict winter foliage color of japanese-cedar; however, it is unclear if measurement of seedlings is a strong predictor of eventual performance of mature trees.

There was a substantial difference in rainfall between the 2 years of the study. From Nov. 2007 to Sept. 2008, the evaluation plot received $112 \mathrm{~cm}$ of precipitation, whereas from Oct. 2008 to Aug. 2009, there was $143 \mathrm{~cm}$ of rain. Supplemental irrigation was only used for short periods during new plant establishment; therefore, the $30-\mathrm{cm}$ difference in rainfall between the 2 years likely had a confounding effect on the study. Most of the native range of japanese-cedar receives between $120 \mathrm{~cm}$ and $180 \mathrm{~cm}$ of rainfall; however, the optimum growing conditions appear to be the north-facing slopes of Japan that receive between 180 and $300 \mathrm{~cm}$ of precipitation. Our Tifton, GA, site has a southfacing slope and receives $\approx 120 \mathrm{~cm}$, the low end reported to sustain japanese-cedar. Furthermore, the field soil [Tifton loamy sand (fineloamy, siliceous, thermic Plinthic Paleudult)] has low water-holding capacity, further limiting the available water. Other studies also have reported that drought stress was a major limiting factor in the survival of plants from northern Japan (Widrlechner et al., 1998). There was a $17 \%$ lower level of $C_{a+b}$ during the first year of the study under reduced precipitation (Table 2). This effect is lower than but consistent with the trend observed by Guerfel et al. (2009) for two olive cultivars that showed an average of $36 \%$ reduction in chlorophyll contents under drought stress. It is possible that we would have observed a similar reduction under comparable drought stress, but we did not quantify leaf water potential or other metrics to precisely measure the level of stress. Anecdotal evidence is also provided by growers in the southeastern United States who have reported that increased irrigation on japanese-cedar before, and during, winter maintains greener foliage than when the substrate/soil is allowed to dry in both containerized and field-grown plants (personal communication).

The current research was conducted to evaluate several biochemical properties of japanese-cedar grown in USDA Zone 8 and determine if there was a relationship with winter color. We sought to identify a single biochemical property such as chlorophyll content that would allow early screening of seedlings to predict winter browning of foliage or lack thereof. We determined chlorophyll, carotenoids, and their ratio can be used to explain greenness in mature japanesecedar taxa. As a result of the importance of drought stress in landscape performance of japanese-cedar, different results may be obtained if consistent supplemental irrigation is used such that water is not limiting. Also, performance of a number of cultivars that were included as replicates in the current 
study is altered when grown in cooler climates that are more similar to the native range of the species (personal observation). Japanese-cedar has a native range that includes Akita Prefecture, Japan, which has a mean yearly temperature, mean yearly high temperature, and mean yearly low temperature of $11.1,15.1$, and $7.4{ }^{\circ} \mathrm{C}$ compared with 18.6, 24.4, and $12.6{ }^{\circ} \mathrm{C}$ for Tifton, GA. The increased temperature coupled with the relatively low rainfall of Tifton, GA, and other USDA Zone 8 sites often results in poor performance of cultivars. Some cultivars that languished in the current study have performed much better in cooler climates (USDA Zone 6 to 7; personal observation), but all selections exhibit increased winter browning in cooler climates. Even in areas as near as Athens, GA (USDA Zone 8a), 10-year-old specimens of 'Yoshino' planted on the University of Georgia campus exhibit a marked increase in winter browning compared with comparable size plants in Tifton, GA (personal observation). The increase in winter browning likely is the result of the lower temperatures being more limiting to enzymatic reactions, causing the plant to rely more heavily on the xanthophyll cycle to dissipate excess energy to prevent oxidative damage.

\section{Literature Cited}

Cox, T. and J.M. Ruter. 2013. Landscaping with conifers and ginkgo for the southeast. University Press of Florida, Gainesville, FL.

Dirr, M.A. 2009. Manual of woody landscape plants: Their identification, ornamental characteristics, culture, propagation and uses. 6th Ed. Stipes, Champaign, IL.

Eckenwalder, J.E. 2009. Conifers of the world: The complete reference. Timber Press, Portland, OR.

Erhardt, W. 2005. List of conifer names. Ulmer, Stuttgart, Germany.

Farjon, A., N. Tien Hiep, D.K. Harder, P. Ke Loc, and L. Averyanov. 2002. A new genus and species in Cupressaceae (Coniferales) from northern Vietnam, Xanthocyparis vietnamensis. Novon 12:179-189.

Guerfel, M., O. Baccouri, D. Boujnah, W. Chaïbi, and M. Zarrouk. 2009. Impacts of water stress on gas exchange, water relations, chlorophyll content and leaf structure in the two main Tunisian olive (Olea europaea L.) cultivars. Sci. Hort. 119:257-263.
Han, Q., S. Katahata, Y. Kakaburi, and Y. Mukai. 2004. Seasonal changes in the xanthophyll cycle and antioxidants in sun-exposed and shaded parts of the crown of Cryptomeria japonica in relation to rhodoxanthin accumulation during cold acclimation. Tree Physiol. 24:609-616.

Han, Q. and Y. Mukai. 1999. Cold acclimation and photoinhibition of photosynthesis accompanied by needle color changes in Cryptomeria japonica during the winter. J. For. Res. 4:229234.

Han, Q., K. Shinohara, Y. Kakubari, and Y. Mukai. 2003. Photoprotective role of rhodoxanthin during cold acclimation in Cryptomeria japonica. Plant Cell Environ. 26:715-723.

He, W.Z. and R. Malkin. 1998. Photosystems I and II, p. 29-43. In: Raghavendra, A.S. (ed.). Photosynthesis: A comprehensive treatise. Cambridge University Press, New York, NY.

Hoober, J.K. 1998. Chloroplast structure and development, p. 3-17. In: Raghavendra, A.S. (ed.). Photosynthesis: A comprehensive treatise. Cambridge University Press, New York, NY.

Ida, K. 1981. Eco-physiological studies on the response of taxodiaceous conifers to shading, with special reference to the behaviour of leaf pigments. I. Distribution of carotenoids in green and autumnal reddish brown leaves of Gymnosperms. Bot. Mag. Tokyo 94:41-54.

Lambers, H., F.S. Chapin, III, and T.L. Pons. 1998. Photosynthesis, p. 10-89. In: Lambers, H., F.S. Chapin III, and T.L. Pons (eds.). Plant physiological ecology. Springer, New York, NY.

Lemke, H.D., M.J. Raupp, and P.M. Shrewsbury. 2005. Efficacy and costs associated with the manual removal of bagworms, Thyridopteryx ephemeraeformis, from Leyland cypress. J. Environ. Hort. 23:123-126.

Lewandowska, M. and P.G. Jarvis. 1977. Changes in chlorophyll and carotenoid content, specific leaf area and dry weight fraction in sitka spruce, in response to shading and season. New Phytol. 79:247-256.

Lichtenthaler, H.K. and A.R. Wellburn. 1983. Determinations of total carotenoids and chlorophylls $a$ and $b$ of leaf extracts in different solvents. Biochem. Soc. Trans. 11:591-592.

Marquard, R.D. and J.L. Tipton. 1987. Relationship between extractable chlorophyll and an in situ method to estimate leaf greenness. HortScience 22:1327.

Martinez, A., J. Williams-Woodward, and M. Pearce. 2009. Diseases of Leyland cypress in the landscape. Univ. of Georgia Coop. Ext. Bul. 1229.

Netto, A.T., E. Campostrini, J.G. de Oliveira, and R.E. Bressan-Smith. 2005. Photosynthetic pigments, nitrogen, chlorophyll a fluorescence and SPAD-502 readings in coffee leaves. Sci. Hort. 104:199-209.

Oserkowsky, J. 1932. Relation between the green and the yellow pigments in chlorotic leaves. Plant Physiol. 7:711-716.

Ottander, C. and G. Öquist. 1991. Recovery of photosynthesis in winter-stressed Scots pine. Plant Cell Environ. 14:345-349.

Robakowski, P. 2005. Susceptibility to lowtemperature photoinhibition in three conifers differing in successional status. Tree Physiol. 25:1151-1160.

Rouse, R.J., P.R. Fantz, and T.E. Bilderback. 2000. Descriptions and a key to cultivars of Japanese cedar cultivated in the eastern United States. HortTechnology 10:252-266.

Sandmann, G. and H. Scheer. 1998. Chloroplast pigments: Chlorophylls and carotenoids, p. 44-57. In: Raghavendra, A.S. (ed.). Photosynthesis: A comprehensive treatise. Cambridge University Press, New York, NY.

Sjöberg, K. 1931. Beitrag zur kenntnis der bildung des chlorophylls und der gelben pflanzenpigmente. Biochem. Z. 240:156-186.

Tripp, K.E. 1993. Sugi: The ancient Japanese cedar finds new life in a profusion of outstanding cultivar forms. Amer. Nurseryman 178:26-39.

Tripp, K.E. 2005. 'Yoshino': An outstanding cultivar of Japanese cedar. Arnoldia 63:13-14.

Tripp, K.E. and J.C. Raulston. 1992. Cryptomeria evaluations at the NCSU Arboretum. Proc. 37th Ann. Southern Nurs. Assoc. Res. Conf. 37: 336-339.

Tsukada, M. 1967. Vegetation and climate around 10,000 B.P. in central Japan. Amer. J. Sci. 265:562-585.

USDA-ARS. 2012. Plant hardiness zone map. 7 Feb. 2013. <http://planthardiness.ars.usda. gov>.

von Euler, H. and H. Hellström. 1929. Über die bildung von xanthophylls, carotin und chlorophyll in belichteten und unbelichteten gerstenkeimlingen. Hoppe Seylers Z. Physiol. Chem. 183:177-183.

Widrlechner, M.P., J.B. Hebel, D.E. Herman, J.K. Iles, G.J. Kling, A.P. Ovrom, J.C. Pair, E.T. Paparozzi, S.R. Poppe, N. Rose, R.E. Schutzki, C. Tubesing, and D.K. Wildung. 1998. Performance of landscape plants from northern Japan in the north central United States. J. Environ. Hort. 16:27-32.

Wolf, F.T. 1956. Changes in chlorophylls $A$ and $B$ in autumn leaves. Amer. J. Bot. 43:714718.

Yadava, U.L. 1986. A rapid and nondestructive method to determine chlorophyll in intact leaves. HortScience 21:1449-1450. 